\title{
A Review on the Relationship Between Portfolio Concentration and Fund Manager Performance
}

\author{
Xinyao Liu ${ }^{1, *, a, \dagger}$ Bixue Tang ${ }^{2, *, b, \dagger}$ \\ ${ }^{1}$ Northeast Agricultural University, Harbin, China \\ ${ }^{2}$ Dongbei University of Finance and Economics, Dalian, China \\ ${ }^{*}$ Corresponding author.Email: ${ }^{a}$ liuxinyao@neau.edu.cn bbm2018211794@sii.dufe.edu.cn \\ ${ }^{t}$ These authors contributed equally.
}

\begin{abstract}
In the process of economic operation, along with the cyclical changes, the various industries in the market also show a different development state. Therefore, in investment activities, the choice of industry is particularly important. When investing in the fund, whether the fund manager can choose the high-quality industry to invest in the numerous industries and whether the fund can get excess returns has become an important content to study the investment management ability of the fund manager. This paper studies the relationship between the fund investment industry allocation and the fund manager performance from a comprehensive perspective, and summarizes its evaluation indicators. By summarizing the investment portfolio and its performance of various funds at home and abroad, we find that the concentration degree and the index of industry investment are the keys for fund managers to choose industry investment. At the same time, there is a significant negative correlation between the industry concentration degree of fund portfolio and fund performance. Therefore, we suggest that fund managers should follow a sound investment style and diversified investment when making investment strategies, and should make timely adjustments when they find that their portfolio is risky or has an obvious bias.
\end{abstract}

Keywords : Portfolio, Industry Concentration, Fund Manager Performance

\section{INTRODUCTION}

The performance evaluation of fund managers has always been the focus of research by domestic and foreign scholars. And industry configuration is critical to its performance. The changes in the industry follow the changes in the macroeconomic and national policies, and the process of change is clearly cyclical and rotating. Fund managers need to make judgments on the capital market based on macro indicators, so as to allocate funds to various industries and specific stocks and funds. Busse and Tong found that the contribution of industry configuration to performance can reach more than onethird [1]. At present, there are few explanations for the above problems from the perspective of industry allocation. The only representative foreign scholars such as Kacperczyk are the industry concentration studies of U.S. funds [2]. The domestic performance evaluation of fund managers still remains on the redemption issue of open-end funds, the relationship with the flow, etc. There are few studies on the relationship between the industry configuration and the performance. Even if there are the research sample time being as short as six months or one quarter of performance data, which cannot fully reflect the investment rotation of fund managers in the investment industry. Studying the performance of fund managers from the perspective of industry configuration has important theoretical and practical significance. Industry allocation is an important part of determining the performance of fund managers. It is important to clarify the relationship between the performance and the industry allocation to comprehensively and objectively evaluate the management and investment capabilities of fund managers, as well as the fund asset allocation research and the fund initiative research. At the same time, it provides a basis for investors to choose funds, and provides a reference for fund companies to make decisions about capital inflows. 


\section{THE RELATIONSHIP BETWEEN PORTFOLIO CONCENTRATION AND FUND MANAGER PERFORMANCE}

\subsection{A review on the relationship}

In the research on the relationship between fund industry allocation and fund manager performance, examine the performance of fund managers by studying the industry concentration of fund allocation, and then analyze the correlation relationship. Scholars have done research in recent decades. The concentration of the investment portfolio is the industry concentration of investment, which refers to the proportion of the total investment in an industry to the fund's investment assets.

Zhang Xin, a domestic scholar, believes that fund managers should manage their funds in accordance with market conditions, and cannot overcome market headwinds [3]; Kong Dongmin, Li Jieyu, etc. used Kacperczyk and other model methods to study the concentration of 12 industries, and the relationship between the industry concentration of the fund's investment portfolio and its performance was negatively correlated [4]; Kong Dongmin and Xie Hongtao also found that the industry concentration of funds is negatively correlated with their performance [5]; Han Yan found that the industry concentration of fund investment can represent the company's ability, so the performance in the fund holding process will be better [6]; Fan Xin'an's research results on the 2007-2008 fund market have shown that most fund managers will choose a centralized investment, regardless of whether the market is positive or not [7]; Qiu Yongde selected 170 open-end stock funds from 2004 to 2009 as the research sample. Results have shown that the relationship between industry investment concentration and the performance of fund managers is not significant. Instead, the concentration of fund holdings was related to the performance of fund managers [8]; Research by Tian Shu and other scholars has shown that in the investment process, fund managers should focus on the three factors of industry development, regional development level and industry development, in order to have a certain degree of selectivity and preference for industry concentration [9].

Similarly, foreign scholars Kacperczyk and others first study the correlation between the investment of fund managers and industry concentration [2]. Hiraki et al. conducted research on global fund companies, fund managers' investment preferences and industry relevance. The research shows that fund managers prefer both the industry and the national investment [10]; Chen et al. believe that the fundamental reason why fund managers' investment scale will affect their performance is diseconomies of scale. Therefore, investments in different industries will have a negative impact on fund managers' performance to a certain extent [11]; Scholars such as
Kacperczyk conducted an empirical analysis on the relationship between the concentration of the fund industry and its performance in 2005. Research shows that the industry has higher investment concentration and higher fund returns. In the investment process, there will also be window decorations, which will affect the performance of the fund through the price of the stock [12]; Scholars such as Agarwal have also conducted research on the industry investment concentration of mutual funds. They believe that due to the window decoration behavior in the mutual fund market, fund companies will deploy large-scale government products before investment choices to make their investment portfolios more reliable [13]; Musto believes that bond funds will also have the same situation, so they will also increase the security and reliability of their investment portfolios by increasing their holdings of governmentissued products, thus highlighting their good performance [14]; Thomson Reusters et al. conducted a survey of listed companies in 2009. The survey results have shown that in order to improve the accuracy of their investments, fund managers conduct private surveys on familiar companies and industries, and obtain relevant investment data by visiting companies. Information advantage, to a certain extent, affects whether its investment portfolio is concentrated or decentralized [15].

In general, domestic research is still based on foreign research conclusions, and appropriate improvements have been made in accordance with the actual conditions of the domestic capital market. But the basic judgment remains the same, that is, industry investment concentration has a negative relationship with fund performance.

\subsection{A Summary of Evaluation Indexes for the Relationship}

Based on the research of industry concentration and fund manager performance, the industry concentration index and the relationship have been analyzed. Two main indicators are used in China. The first is Kacperczyk's method, a method of constructing industry concentration ICI; The second is the method of constructing GT indicators.

The domestic scholar Niu Zhidong put forward the indicator of "positive ratio of industry level" to measure the concentration of fund investment industry. He took index funds as the research object and used the CAPM model and the three-factor model to compare and adjust the returns of the funds. The research found that indicator had a positive impact on the performance of fund managers, and could improve the efficiency of fund allocation at the industry level to obtain excess returns [16]; Liao Changyou took open-end stock funds as the research object, and proposed that ICI and GT indicators can evaluate the industry concentration of funds, and his research results have shown that fund managers' active 
industry allocation strategies have no clear relationship with returns that exceed the market average [17]; Based on the research of Kacperczyk and other scholars, Xing Xinyi proposed revised ICI, ICR, and ASR indicators as the evaluation indicators of the relationship between industry allocation and fund performance. The research has shown that the performance of open-end stock funds has a positive relationship with industry investment concentration [18]; Scholars such as Lou Jun have shown through empirical research that the greater the concentration of the fund investment industry, the worse the performance of fund managers. Through further analysis of the stability of fund returns, the higher the concentration of industry investment, the greater the probability of a continuous decline in the rate of return, and pointed out that fund managers Diversified investment [19]; Geng Yuxuan took the relationship between industry and income in the A-share market from 2001 to 2006 as the research object. The research has shown that in the A-share market, industry concentration is positively correlated with income [20]; Zhang Xueyong and others conducted an empirical study on domestic active funds from 2004 to 2013, and proposed a Returnbased model. They proposed that the concentration and activity of the investment industry have a positive impact on the performance of fund managers. There is no significant relationship between fund net flow, and industry activity has a positive impact [21]; Wang Xiaohui further evaluated the impact of investment industry concentration on the performance of fund managers. The research has shown that the contribution is about $3 \%$. At the same time, the time period of industry allocation is distinguished. During the bull market and the market turbulence, they have a significant positive correlation, that is, under the high industry concentration, they have obtained a return rate that exceeds the market benchmark portfolio; and during the bear market, both show a significant negative correlation. That is, compared with the average market return, the fund performance is poor [22].

The indicator of foreign scholars' allocation of the fund industry is the Industry Concentration Index proposed by scholars such as Kacperczyk. ICI is based on Herfindahl. The larger the index, the greater the investment weight of fund managers in the industry, and the greater the fund industry concentration index. Funds perform better than funds with a small industry concentration index [23]. If the fund is a centralized investment, Herfindahl will be lower than the portfolio of the entire market, and ICI will not be affected by it, because its minimum value is 0 .

$$
\begin{gathered}
\text { Industry Concentration Index }=\sum_{i=1}^{10}\left(W_{\text {fund }, i}-\right. \\
\left.W_{\text {index }, i}\right)^{2}(1)
\end{gathered}
$$

Where $W_{j}$ is the weight of the fund in the J-th industry, $W_{i}$ is the weight of the benchmark portfolio in the industry. The research results show that there is a significant positive correlation between industry concentration and fund managers' performance. At the same time, the author explains when investing in certain industries, it is because of a detailed analysis of the industry that these industries are selected for allocation. Therefore, the more concentrated the industry, the better the fund performance will be. On this basis, scholars such as Cremers and Petajisto proposed the AC-TIVE Share indicator to measure the management level of fund managers [24]. Since this indicator is a single-period indicator, it needs to be based on a certain time node to test the deviation of the industry configuration from the industry configuration of the benchmark index fund.

$$
\text { AC-TIVE Share }=\frac{1}{2} \sum_{i=1}^{N}\left|W_{\text {fund }, i}-W_{\text {index }, i}\right|
$$

Hashem used a three-factor model to prove that there is a negative correlation between industry concentration and fund performance, and its contribution is about onethird of the total performance [25]. In the research of Sohn, Kim, and Shin, it is found that the relationship between fund asset concentration and fund performance can be clarified after controlling the individual characteristics of the fund. Research has shown that fund managers perform better in fund portfolios with more concentrated asset allocation. It is mainly affected by factors such as asset liquidity, idiosyncratic risks, etc [26]. When Chou and Lee studied the investment strategies of fund managers, they found that when evaluating the relationship between industry investment concentration and fund managers, the premium of the market portfolio is a relatively objective evaluation indicator [27]. The study found that when the investment industry concentration is low, the premium of the market portfolio has a greater impact on the fund performance: the industry concentration is higher, and the risk is lower. Choi, Fedenia, and Skiba studied global fund data and found this research conclusion.

Sun Yang used DEA method to evaluate the performance of 36 Chinese funds from September 2016 to December 2018 and conducted a sustainability test. It was found that the performance of the sample funds had statistically significant sustainability within three months, but the sustainability became weaker as the observation time went on. Over half a year's observation window period, about $50 \%$ in the total time interval are part of the present a certain continuity; the interval to a year, fund performance continued phenomenon is not obvious, and the fund performance persistence exists in a more economic upward period, in the opposite direction in the economic times are prone to extreme changes in the ranking, and the sustainability is relatively weak [28]. Du Chinglian studied the data of 410 actively managed funds in recent five years by using the classic contingency table method at the macro level and the scanning system method at the micro level. The empirical findings at the macro level were as follows: when using the return rate without risk adjustment, only the short-term (six months) 
fund performance has a certain degree of sustainability, the time series of more than six months to see the fund is not sustainable; When the risk-adjusted rate of return is used to calculate, the fund performance of the three periods has a certain degree of continuity, and the intensity of continuity is strongest in the middle, second in the short and weakest in the long run [29]. Ladies lee study found that the domestic open funds performance persistence in monthly and weekly level is significant, but pull the observation window and long-term sustainability will increasingly lead to inadequate performance. Different categories funds show the continuity condition is different, mixing and bond funds generally. There are few results in long-term reversal phenomenon. But the performance of the stock fund in the short term is sustained, long-term will appear obvious reversal [30]. According to Lu Rong study, a phenomenon known as "redeemed vision" exists in China open-end fund market, according to the reason for rising fund performance when investors will continue to add positions, but domestic investors will choose to redeem at this time. The scholars think that this is mainly because that the fund is not how to share out bonus, and most investors expected performance retracement [31]. Xiao Jun and Shi Jin pointed out that if we focus on the relationship between the medium and long-term performance of the fund rather than the short-term performance and the fund capital flow, the so-called "redemption anomaly" is less likely to exist, and domestic investors are generally chasing the funds with good performance [32]. Luo Neng made use of the portfolio data of domestic mutual funds from 2005 to 2017 to explore whether the concentrated investment strategy can bring a higher level of return to the public offering fund compared with the diversified investment strategy [33]. For different fund performance indicators, it is found that there is a significant positive correlation between portfolio concentration and risk-adjusted returns of mutual funds. From the perspective of relative fund performance ranking, Anna Shen conducted an empirical study on 204 stock-biased funds that existed continuously from 2008 to 2017 and concluded that there was no significant correlation between the concentration of shares in the portfolio of hybrid funds and their performance ranking values, which was true under different market trends [34]. However, in the volatile market, there is a significant positive correlation between the holding concentration of the fund portfolio and the fund performance ranking, and the adjustment trend of the holding concentration of the winner fund in the previous period and the loser fund in the next period is opposite. Cheng Yongwen, Zhu Chengke and Tang Yan used Jenson model and HM model to study the hybrid openend funds in China from January 2014 to June 2019 and found that the overall performance of the hybrid funds in the open-end funds was better than the general market, and the overall stock selection ability of China's public offering funds was relatively significant. Looking only at the timing ability is disappointing, not only this, fund managers' timing ability and stock-picking ability indicators also show a negative statistical correlation [35]. Sui Tingting used the method of Ferson and Mo to evaluate fund performance to test its effectiveness in China's open-end fund market and found that China's open-end funds from 2015 to 2017 had significant market timing and volatility timing ability [36]. However, there is not enough evidence to prove that the sample funds have positive stock selection ability and stock selection ability also has a negative effect on the total performance of the fund.

\section{CONCLuSion}

Based on the above research, we find that in studying the selection behavior of fund managers in industry investment, the concentration of industry investment and the index of concentration are the key. Compared with the foreign research, the domestic research adopts a shorter data set and a single method. And at the same time, it is not as accurate as the foreign literature in terms of the accuracy of constructing indicators. Many domestic scholars have simply performed regression analysis when estimating the rate of return of the fund, but this does not fully reflect the true performance level. The most important thing is that some domestic scholars on the relationship between industry investment concentration and fund managers have reached the opposite conclusion to foreign researchers. That is, the relationship between industry configuration concentration and fund managers' performance is inversely proportional. Therefore, in future research, research scholars should first increase the sample time of the research object to cover the large cycle of the investment industry, so as to objectively show the cyclical relationship between the industry investment and the performance; second, focus on the performance of fund managers' evaluation should be more objective rather than the simple regression analysis.

\section{REFERENCES}

[1] Busse J A, Tong Q. Mutual Fund Industry Selection and Persistence[J]. Social Science Electronic Publishing, 2007, 2(2):245-274.

[2] Stevens L, Nosal J, Kacperczyk M. Investor Polarization, Trading Volume, and Return Dynamics[C]// 2013 Meeting Papers. Society for Economic Dynamics, 2013.

[3] ZHANG Xin, DU Shuming. Can China Securities Investment Fund Beat the Market? [J]. Journal of Financial Research, 2002(01):1-22.

[4] KONG Dongmin, LI Jieyu, XING Jingping, et al. A study of portfolio industry concentration and fund performance $[\mathrm{J}]$. Management Review, 2010, 22(004):17-25. (in Chinese) 
[5] Xie Hongtao, Zhou Shaofu. Research on asset allocation concentration of stock funds and investment performance [J]. Securities Market Review, 2008, 2008(005):52-56. (in Chinese)

[6] Han Yan, Cui Xin. Management Review, 2014, 26(009):34-45. (in Chinese with English abstract)

[7] Fan Xin 'an. Analysis on the overall stock selection and timing ability of Chinese open-end stock funds [J]. Journal of Finance and Accounting: Theoretical Edition (2), 2010, 000(007):43-46. (in Chinese)

[8] D Agarwal. How Prince Ranbir Found Knowledge[J]. cricket, 2010.

[9] Jiang Ping, Tian Shu, Cheung Yan-leung. Research on Equity Structure and Fund Performance of Fund Management Companies [J]. Financial Research, 2011(06):123-135.

[10] Hiraki A, Koolen J, Bannai E, et al. Annals of Combinatorics An Improvement of the Godsil Bound.

[11] Richburg K B. Chen Guangcheng's nephew found guilty of assault in China; sentenced to 39 months (Posted 2012-12-01 15:12:17); Chen Kegui used knife to ward off agents who burst into home searching for Chen Guangcheng.

[12] Qiu Yongde. A study on the relationship between open-end stock fund performance and stock allocation concentration $[\mathrm{J}]$. Friends of Accounting, 2010(9):83-85. (in Chinese)

[13] Musto D F. Cocaine's history, especially the American experience. [J]. Ciba Foundation Symposium, 1992, 166:7.

[14] Wright V, Eastmond C J, Hinchcliffe R, et al. Society Notices Details of meetings to be held, and other announcements, will be found in the centre pages of[J]. 1978.

[15] Liao Changyou. Fund Asset Allocation Industry Selection and Fund Performance: New Evidence of Fund Manager's Investment Capability [J]. Journal of Chongqing University (Social Science Edition), 2013(04):53-60.

[16] Xing Xinyi, Sun Qian. Research on the correlation between industry allocation and performance of open-ended funds in China $[\mathrm{J}]$. Modern Management Science, 2015, 000(001):63-65. (in Chinese)

[17] Lou Junqiang. An empirical analysis on the location choice of multinational corporations' R\&D investment in China [J]. International Trade Issues, 2008(05):99-108.
[18] LIU Hao, TANG Song, LOU Jun. Independent Directors: Supervisory or Consulting? Management World, 2012, 000(001):141-156. (in Chinese)

[19] Geng Yuxuan. An Empirical Study on the Influence of Industry Concentration on Excess Return in China's A-share Market [D]. Capital University of Economics and Business.

[20] ZHANG Xueyong, LIAO Li. Venture capital background and IPO: market performance and internal mechanism [J]. Economic Research Journal, 2011.

[21] Marcin, Kacperczyk, Philipp, et al. Implicit Guarantees and Risk Taking: Evidence from Money Market Funds Marcin Kacperczyk and Philipp Schnabl[J]. Working Paper, 2011.

[22] Fraser-Abder, Pamela,Doria, John A,Yang, Ji-Sup, De Jesus, Angela. Using Funds of Knowledge in an Ethnically Concentrated Classroom Environment to Teach Nutrition[J]. Science Activities,2010,47(4).

[23] Pesaran M H, Shin Y, Smith R J. Bounds testing approaches to the analysis of level relationships[J]. Journal of Applied Econometrics, 2010, 16(3):289326.

[24] Kim H, Sohn H J, Kim S, et al. New staging systems can predict prognosis of multiple myeloma patients undergoing autologous peripheral blood stem cell transplantation as first-line therapy. [J]. Biology of Blood \& Marrow Transplantation Journal of the American Society for Blood \& Marrow Transplantation, 2006, 12(8):837-844.

[25] Hay R L, Lee M, Kolata D R, et al. Episodic potassic diagenesis of Ordovician tuffs in the Mississippi Valley area[J]. Geology, 1988, 16(8):743.

[26] Choi N, Fede Nia M, H Skib. Information Acquisition, Under-Diversification and Portfolio Performance of International Investors. 2011.

[27] Craig L Israelsen. Characteristics of winning mutual funds [J]. Journal of Financial Planning,1998,11(2)

[28] Soumya Guha Deb. Persistence in performance of actively managed equity mutual funds: New Indian evidence[J]. IIMB $\quad$ Management Review,2019,31(2).

[29] David Hunter,Eugene Kandel,Shmuel Kandel,Russ Wermers. Mutual fund performance evaluation with active peer benchmarks[J]. Journal of Financial Economics,2014,112(1).

[30] Eugene F. Fama, Kenneth R. French. A five-factor asset pricing model[J]. Journal of Financial Economics,2015,116(1). 
[31] Fama Eugene F.,French Kenneth R.. Common risk factors in the returns on stocks and bonds[J]. ,1993,33(1).

[32] David Feldman,Konark Saxena,Jingrui Xu. Is the active fund management industry concentrated enough? [J]. Journal of Financial Economics,2019.

[33] Hyung-Suk Choi,Doojin Ryu,Sangik Seok. The turnof-the-year effect in mutual fund flows[J]. Risk Management,2017,19(2).

[34] Eugene F. Fama,Kenneth R. French. International tests of a five-factor asset pricing model[J]. Journal of Financial Economics,2016.
[35] Flori Andrea,Pammolli Fabio,Buldyrev Sergey $\mathrm{V}$,Regis Luca,Stanley H Eugene. Communities and regularities in the behavior of investment fund managers. [J]. Proceedings of the National Academy of Sciences of the United States of America,2019,116(14).

[36] Cremers M, Petajisto A. How Active is Your Fund Manager? A New Measure That Predicts Performance[J]. Yale School of Management Working Papers, 2009, 22(9):3329-3365. 